\title{
Santral Sinir Sistemi Tutulumu Sonrası Geç Tanı Alan İleri Yaş Sistemik Lupus Eritematosus: Olgu Sunumu
}

\author{
Late-Onset Advanced Age Systemic Lupus Erythematous \\ After Central Nerveus System Involvement: Case Report
}

Fatma Şimşek ${ }^{1}$,

Nuray Bilge ${ }^{1}$,

Gökhan Aydoğan ${ }^{1}$

${ }^{1}$ Atatürk Üniversitesi, Tıp Fakültesi, Nöroloji Anabilim Dalı, Erzurum, Türkiye

Geliş Tarihi/Received: 22 Mart 2019

Kabul Tarihi/Accepted: 12 Ağustos 2019

\section{Öz}

Sistemik lupus eritematozus, otoimmün karakterli, bir çok sistemi tutan inflamatuar bir hastalıktır. Hastalık bazen sinsi bir sekilde seyrederek yıllarca ates, halsizlik, yorgunluk semptomları ile seyredebilir. Merkezi sinir sistemi tutulumu yaygındır. Klinik değişken olup çok hafif olabileceği gibi çok ağırda olabilir. Hastaların çoğunda başlangıç yaşı 16-55 yaş arasında olup, ileri yaşta tanı alan vakalarda bulunmaktadır. Burada 80 yaşında iken baş dönmesi ve sağ taraf kuvvetsizliği gelişen, 85 yaşında lupus tanısı alan ileri yaş hasta sunulmuştur. Hastanın hem çok ileri yaş olması hemde lezyonların demiyelinizan plaklara benzer özellikte olması nedeniyle sunmaya değer bulduk. İleri yaş olgularda santral sinir sistemi tutulumunda ayırıcı tanıda lupus unutulmamalıdır.

Anahtar Kelimeler: Sistemik lupus eritematozus, hemiparezi, demiyelinizan bozukluklar, santral sinir sistemi tutulumu.

Yazışma Adresi: Fatma Şimşek, Atatürk
Üniversitesi, Tıp Fakültesi, Nöroloji Anabilim Dalı, Erzurum, Türkiye

e mail: klamaks@hotmail.com

\section{ORCID}

Fatma Şimşek

https://orcid.org/0000-0003-1662-5534 Nuray Bilge

https://orcid.org/0000-0002-9328-1678 Gökhan Aydoğan

https://orcid.org/0000-0003-4249-6860

\begin{abstract}
Systemic Lupus Erythematous, autoimmune character, is a inflammative disease holding many systems. The disease can sometimes follow insidiously with symptoms of fever, asthenia and prostration for years. Central nervous system is common. It is the clinical variable and may be very mild or very severe. In most patients, the age of onset is between 16-55 years old and is found in cases diagnosed in advanced age. Here, it is presented an elderly patient developed dizziness and right side prostration when she was 80 and diagnosed lupus when she was 85 . We thought as worth for presenting because of that both the patient is elder and that the lesions have similar features with demyelinating plaques. The lupus should not be forgotten in the central nervous system involvement in advanced age cases and separator diagnosis.
\end{abstract}

Key words: Systemic lupus erythematosus, hemiparesis, demyelinating disorders, central nerveus system involvement.
Atıf yapmak için: Şimşek F, Bilge N, Aydoğan G. Santral Sinsir Sistemi Tutulumu Sonrası Geç Tanı Alan Ileri Yaş Sistemik Lupus Eritematosus: Olgu Sunumu. Selcuk Med J 2020;36(3): 259-263

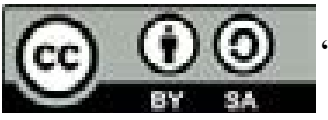

Açıklama: Yazarların hiçbiri, bu makalede bahsedilen herhangi bir ürün, aygıt veya ilaç ile ilgili maddi çıkar ilişsisine sahip değildir. Araştırma, herhangi bir dıs organizasyon tarafından desteklenmedi. Yazarlar çalıșmanın birincil verilerine tam erişim izni vermek ve derginin talep ettiği takdirde verileri incelemesine izin vermeyi kabul etmektedirler. 


\section{GíRiş}

Sistemik lupus eritematozus (SLE), kronik, nüks eden, kadın baskınlığı olan, multisistemik, mikrovasküler inflamasyon ile karakterize, merkezi sinir sistemini etkileyebilen otoimmün bir hastalıktır (1). Etiyolojisi tam olarak bilinmemektedir. Santral sinir sistemi, periferik sinir sistemi, otonom sinir sistemi tutulmasından dolayı çeşitli komplikasyonlar ve psikiyatrik belirtiler görülebilir $(2,3)$. Sıklıkla doğurganlık çağındaki kadınlarda görülmektedir ve kadın, erkek oranı 4:1'dir. Tarama testi olarak antinükleer antikor (ANA) kullanılmaktadır. Sensitivitesi yüksek ancak spesifisitesi düşük bir testtir. Tanı American College of Rheumatology (ACR)'nin bildirdiği onbir kriterden dört veya fazlasının olması ile konulur (4). SLE tanı kriterleri tablo 1'de verilmiştir. SLE hastalarında mortalite ve morbiditeyi en çok etkileyen faktörler enfeksiyonlar, renal ve nörolojik tutulumdur. Hastalarda tedavi, klinik bulgulara ve yaşa göre farklılık göstermekte olup hastalığın erken tanınması ve uygun tedavi ile yaşam kalitesi iyileştirilebilmektedir. Burada şikayetleri ileri yaşta başlayan ve tanısı santral tutulumdan 5 yıl sonra konulan ileri yaş SLE olgusu sunulmuştur.

\section{OLGU}

85 yaşında bayan hasta 5 yıl önce olan fakat son bir aydır artan sağ taraf kuvvetsizliği nedeni ile nöroloji polikliniğine başvurdu. Beş yıl önce ani başlayan baş dönmesi, denge bozukluğu, sağ taraf kol ve bacakta kuvvetsizlik tarif ediyordu. Baş dönmesi bir ay devam edip düzelmiş, kuvvetsizliği ise düzelmemişti. Sağ taraf kuvvetsizliği sekel olarak kalan hastanın son bir aydır sağ taraf kol ve bacağını kullanmakta daha da zorlandığı, halsizliği ve arada tekrarlayan diz ağrısı şikayetleri olduğu öğrenildi. Bir ay öncesine kadar tek taraflı destekle yürürken son bir aydır çift taraflı destekle zorlukla yürüyebilir hale gelmişti. Beş yıl önce dış merkezli çekilen manyetik rezonans görüntülemede (MRG) beyinde lezyonları olduğu söylenmiş fakat tanı konulamadığı için hastaya herhangibir ilaç tedavisi başlanmamıştı. Beyindeki lezyonların verem veya tümör yayılımı olabileceği hastaya söylenmiş fakat neden belirlenememiş, tetkikler devam ederken hasta kendi isteği ile takibi bırakmıştı. Fiziki muayenede burun ve yanaklarda düz sabit eritemi vardı (Şekil 1). Sorgulandığında fotosensitivite tarif ediyordu. Nörolojik muayenede, bilinç açık, oryante ve koopere olan hastanın konuşması akıcı, sağ tarafında üst ve alt ekstremitede distal ve proksimallerde $3 / 5$ motor kuvveti vardı, sağda

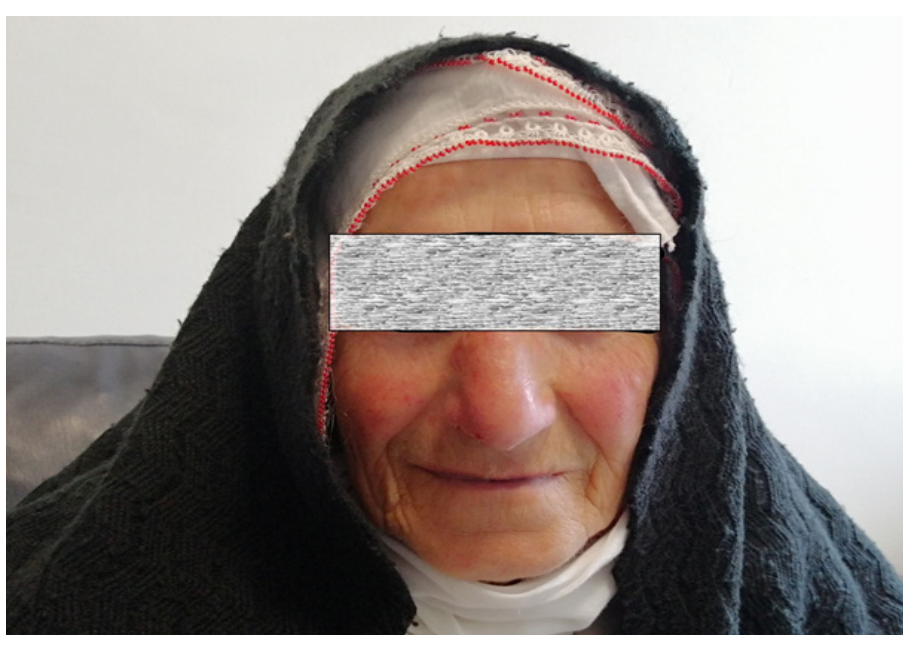

Şekil 1. Burun ve yanaklarda düz sabit eritem izleniyor.

derin tendon refleksleri artmıştı, karın cildi refleksi bilateral normaldi, dokunma-ağrı-ısı duyusunda defisit yoktu, vibrasyon duyusu hasta yaşı itibarı ile koopere olmadığı için değerlendirilemedi, pozisyon duyusu üst ve alt ekstremitede normaldi, taban cildi refleksi bilateral fleksör yanıt alınıyordu. Serebellar testler solda normal, sağda hemiparezi nedeni ile değerlendirilemedi. Özgeçmiş, beş yıl önce gelişen sağ taraf kuvvetsizliği olup etiyolojisi belirlenememişti. Soygeçmişinde özellik yoktu. Hastanın beş yı önce ilk şikayeti sırasında çekilen beyin MRG incelendiğinde multipl sayıda, derin beyaz cevher ve periventrküler yerleşimli, kontrast tutulumu olan lezyonları görüldü (Şekil 2, 3). Son bir aydır şikayetleri artan hastanın yeni beyin MRG'si çekildi, yeni görüntülemede eski lezyonların bazıları izlenirken bazılarının kaybolduğu görüldü, lezyonlarda kontrast tutulumu yoktu (Şekil 4). İlk muayene esnasında yanaklarda düz eritemi olan hastanın vaskülit belirteçleri istendi. ANA(+2), antidsDNA'sı yüksekti. Periventriküler, bazıları korpus kallosuma dik seyirli ve yer yer ovoid şekilli lezyonları olan, eski MRG'sinde bazı lezyonları kontrast tutulum özelliği gösteren hastanın multipl skleroz ayırıcı tanısı için yapılan vizüel uyarılmış potansiyel testi normal, oligoklonal bandı patern 1 olarak geldi. Hastanın beş yı önceki şikayeti dışında tarif ettiği atak ile uyumlu kliniği yoktu. Yüzde eritemi olan, fotosensitivite tarif eden, ANA ve anti-dsDNA'sı pozitif olan, nörolojik tutulumu olan hastaya SLE tanısı konuldu. Fizik tedavi kliniği ile konsulte edilerek hidroksiklorokin sülfat, nonsteroidal antiinflamatuar ilaç ve asetilsalisilik asit başlandı. Hastanın ileri yaş olması, hastalığın uzun 


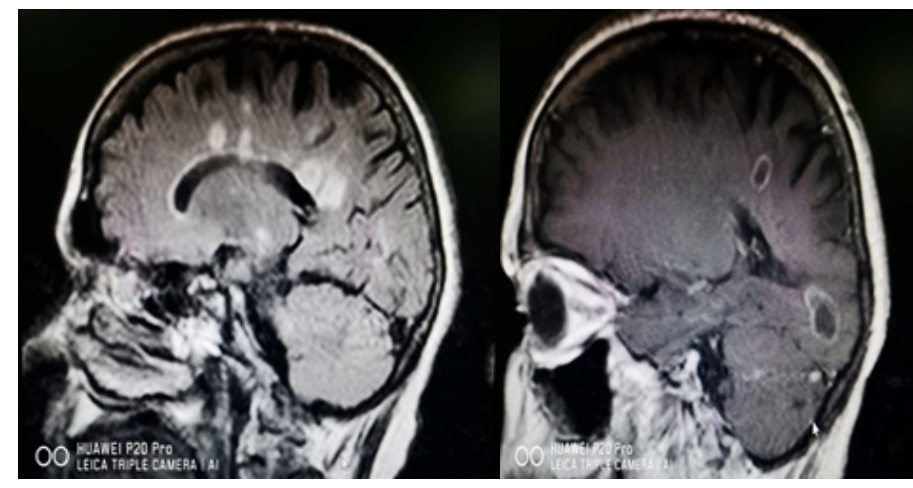

Şekil 2-3. Kranial MRG'de FLAIR sekans sagittal kesitte (solda) multipl sayıda, derin beyaz cevher ve periventrküler yerleşimli, çoğu korpus kallosuma dik seyir gösteren demiyelinizan özellikte plaklar ve T1 kontrastlı çekimde (sağda) bu plakların bazılarının halkasal özellikte kontrast tutulumu gösterdiği izleniyor.

süre sessiz seyretmesi, yeni görüntülemelerinde beyinde aktif, kontrast tutan lezyon bulunmaması ve ilaç yan etkileride düşünülerek hastaya steroid tedavisi başlanmadı. Bir yıllık takipte hastanın tekrarlayan bir atağı izlenmediği gibi kliniğinde düzelmede görülmedi. Hastadan yazılı onam alınmıştır.

\section{TARTIŞMA}

Hastaların \%65'inde başlangıç yaşı 16-55 yaş

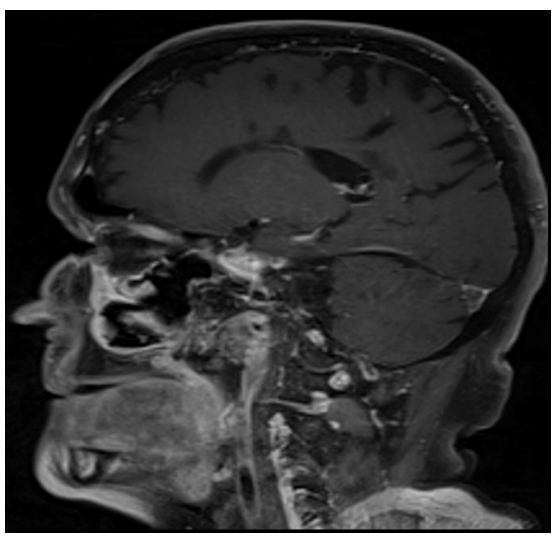

Şekil 4. T1 kontrastlı sagittal kesitte bazıları korpus kallosuma dik seyir gösteren, derin beyaz cevher yerleşimli, kontrast tutulumu olmayan hipointens plaklar izleniyor.

arasında olup, \%15’ 55 yaş üstünde tanı almaktadır. SLE klinik spektrumu oldukça geniş olan multisistemik bir hastalıktır. Tanı için gerekli kriterler farklı zamanlarda ortaya çıkabileceğinden tanı gecikmeleri kaçınılmazdır (5). Hastamız nörolojik tutulum ile başvurusundan beş yıl sonra tanı almıştı ve öncesinde SLE'ye yönelik profilaktik tedavi almamıştı. Hastanın beş yıl önce dış merkezli başvurusunda ilk çekilen kranial MRG'de multipl kontrast tutan lezyonlar görülmesi nedeni

Tablo. American College of Rheumatology (ACR)'nin bildirdiği SLE tanı kriterleri

\begin{tabular}{|c|c|}
\hline 1. Kelebek döküntü & $\begin{array}{l}\text { Yanaklarda ve burun sırtında düz veya kabarık, } \\
\text { nazolabial olukları koruyan sabit eritem. }\end{array}$ \\
\hline 2. Diskoid döküntü & $\begin{array}{l}\text { Keratotik skarlar ve foliküler tıkaçlar gösteren, } \\
\text { deriden kabarık eritemli plaklar. }\end{array}$ \\
\hline 3. Fotosensitivite & $\begin{array}{l}\text { Güneş ışığına reaksiyon olarak gelişen döküntü ve/veya } \\
\text { hastalık belirtilerinde ağırlaşma. }\end{array}$ \\
\hline & Ağrısız, mum alevi şeklinde oral veya nazofarengeal ülserasyon \\
\hline 4. Oral ülserler & İki veya daha fazla eklemde erozyon oluşturmayan artrit \\
\hline 5. Artrit & $\begin{array}{l}\text { a) Plörit: Tipik plöritik ağrı öyküsü veya plöral frotman veya plöral } \\
\text { efüzyon bulguları } \\
\text { b) Serözit: Perikart frotmanı veya EKG veya EKO'da perikart efüzyonu bulguları. }\end{array}$ \\
\hline 6. Serözit & Üç pozitiften fazla persistan proteinüri veya günde 0.5 g'ın üzerinde \\
\hline 7. Böbrek hastalığı & $\begin{array}{l}\text { proteinüri veya hücresel silendirler (eritrosit, hemoglobin, granüler, tubuler } \\
\text { veya karışık } \\
\text { a) Konvülziyonlar (Metabolik bozukluğa ya da bir ilaca bağlı olmayan) }\end{array}$ \\
\hline 8. Nörolojik tutulum & b) Psikoz (Metabolik bozukluğa veya bir ilaca bağlı olmayan) \\
\hline 9. Hematolojik bozukluk & a) Hemolitik anemi veya b) Lökopeni c)Lenfopeni d)Trombositopeni \\
\hline İmmunolojik bozukluk & $\begin{array}{l}\text { a) anti-dsDNA pozitifliği veya b) anti-Sm pozitifliği veya c) Altı aydan beri } \\
\text { devam eden yalancı pozitif sifiliz testleri (VDRL pozitif, TPHA negatif) }\end{array}$ \\
\hline 11. ANA pozitifliği & $1 / 80$ ve üzerindeki titreler. ANA pozitif yapabilecek bir ilaç olmamalı. \\
\hline
\end{tabular}

*Kısaltmalar:ANA:Antinükleer antikor, EKG:elektrokardiyografi, EKO:ekokardiyografi, TPHA: Treponema pallidum hemaglitünasyon, VDRL: Venereal Disease Research Laboratory 
ile o dönem metastaz veya tüberkülom olabileceği şüphesi ile tetkik edildiği öğrenilmiş fakat etiyolojisi tespit edilemediği için tedavi başlanmamıştı. Hastanın lezyonlarına bakıldığında lezyonlar periventriküler ve derin beyaz cevher yerleşimli idi. Lezyonların çoğunda kontrast tutulumu izleniyordu. Beyin metastazlarında tutulum daha çok kortikal alanda izlenmektedir. O dönem hastaya maligniteye yönelik yapılan tarama testleri, PET CT, tüberküloma yönelik yapılan PPD testi, akciğer grafisi ve toraks bilgisayarlı tomografisi normal olarak değerlendirilmişti. Etiyolojisi tespit edilemeyen hasta sonrasında kontrollere gitmediği için tanı konulamamış ve profilaktik herhangi bir tedavi kullanmıyordu.

Son bir aydır kliniğinde kötüleşme nedeni ile tarafımıza başvuran hastanın eski MRG'leri değerlendirildiğinde lezyonların periventriküler yerleşimli, yer yer ovoid şekilli, bazılarının korpus kallosuma dik seyirli ve kontrast tutulumu göstermeleri nedeni ile ayırıcı tanıda demiyelinizan lezyona neden olabilecek hastalıklar düşünüldü. Hastanın beş yıl önce olan ilk atağı ve son bir aydır kötüleşme olarak tarif ettiği şüpheli ikinci atağı vardı. İlk MRG'de kontrast tutan lezyonlar dışında kontrast tutulumu olmayan lezyonların varlığı ve ensefalopati kliniği tarif etmemesi nedeni ile akut demiyelinizan ensefalomyelit tanısından uzaklaşıldı. Hastanın yeni çekilen kranial MRG'sinde eski MRG'si ile benzer lezyonlar olup kontrast tutan lezyonu yoktu, servikal MRG'si normaldi. Demiyelinizan hastalık ayırıcı tanısı için istenen vaskülit belirteçlerinde ANA ve antidsDNA pozitifliği olan, vizüel uyarılmış potansiyel testi normal, oligoklonal bandı normal olan hastada multipl skleroz tanısından uzaklaşıldı. Fakat multipl skleroz hastalarında da değişen oranlarda ANA pozitifliği görülebildiği unutumamalıdır. Yüzde eritemi, nörolojik tutulumu olan, fotosensitivite tarif eden, ANA ve antidsDNA pozitifliği olan hastaya SLE tanısı konuldu.

Hastalarda nöropsikiyatrik tutuluma bağlı klinik bulgular içerisinde yaygın olarak nöbetler, depresyon, psikoz, aseptik menenjit, baş ağrısı, kranial ve periferal nöropatiler yer almaktadır (6). Tüm SLE'li hastalarda nörolojik tutulum olarak strok görülmesi \%3- 20 oranındadır (7). Hastamızın ilk gelişinde sağ hemiparezi sekeli olması nedeni ile geçirilmiş bir serebrovasküler inme olabileceği düşünülmüş fakat o dönem çekilen MRG'leri incelendiğinde difüzyon kısıtlaması gösteren akut enfarktının olmaması, multipl sayıda kontrast tutan lezyonunun olması nedeni ile bu tanıdan uzaklaşılmıştı. İskemiye yönelik etiyolojik incelemede elektrokardiyografi, ekokardiyografi, ritim holter, karotis-vertebral dopler ultrasonografisi, lipit profili normal sınırlardaydı. Yapılan tetkikler sonrası SLE tanısı konulan hastanın beyindeki lezyonlarının SLE'ye bağlı vaskülitik tutulum olduğu sonucuna varıldı. SLE'de en sık görülen MRG bulgusu, küçük, noktasal, subkortikal beyaz maddede yerleşmiş odaklar olup, \%15-60 oranında bildirilmektedir. Bunu kortikal atrofi, periventriküler ak madde değişiklikleri, ventriküler genişleme ve büyük serebral infarktlar izlemektedir $(8,9)$. Olgumuzda lezyonlar çoğunlukla periventriküler yerleşimli ve noktasal özellikte değildi. Yerleşim ve şekil olarak multipl skleroz lezyonlarına benzerlik göstermesi nedeniyle atipik özellikteydi.

Bilişsel işlev bozukluğu, demiyelinizan sendrom, serebrovasküler hastalıklar ve nöbet oluşumu lupuslu hastalarda santral sinir sistemi vasküliti ile ilişkili en sık bildirilen klinik tablolardır $(10,11)$. Hastamızın oldukça ileri yaşta iken santral tutulum sonrası SLE tanısı alması, ileri yaş hastalarda santral sinir sistemini tutan demiyelinizan karakterdeki lezyonların ayırıcı tanısında SLE'nin de akılda tutulması gerektiğini göstermektedir. Hastamızda da olduğu gibi SLE uzun yıllar sessiz bir seyir gösterebilmektedir. Hastalarda nörolojik tutulum, klinik seyri etkileyen önemli faktörlerden biri olduğu için tanı ve tedavideki gecikmeler sekel kalma oranında artmaya ve yaşam kalitesinin kötü yönde etkilenmesine neden olabilmektedir. Tedavi hastaların yaşı ve klinik bulgularına göre değişkenlik göstermektedir.

Çıkar Çatışması: Çalışmada herhangi bir çıkar çatışması yoktur.

Finansal Çıkar Çatışması: Çalışmada herhangi bir finansal çıkar çatışması yoktur.

Yazışma Adresi: Fatma Şimşek, Atatürk Üniversitesi Tıp Fakültesi Nöroloji Anabilim Dalı, Palandöken, Erzurum, Türkiye

Telefon: 05058347780

e-mail: klamaks@hotmail.com

\section{KAYNAKLAR}

1. Ercan E, Magro-Checa C, Valabregue R, et al. Glial and axonal changes in systemic lupus erythematosus measured with diffusion of intracellular metabolites. Brain 2016;139(5):1447-57.

2. Benseler SM, Silverman ED. Neuropsychiatric involvement in pediatric systemic lupus erythematosus. Lupus 2007;16(8):564-71.

3. Greenberg BM. The neurologic manifestations of systemic lupus erythematosus. Neurologist 2009;15(3):115-21.

4. Tan EM, Cohen AS, Fries JF, et al. The 1982 revised criteria for the classification of systemic lupus erythematosus. Arthritis Rheum 1982; 25(11):1271-7. 
5. Ergüven $M$, Katıöz $Y$, Sağlar $N$, et al. Çocukluk dönemi sistemik lupus eritematozus vakalarında farklı klinik tablolar. Jinekoloji Obstetrik Pediatri Dergisi 2004; 10:54-7.

6. Futrell N, Schultz LN, Millikan C. Central nervous system disease in patients with systemic lupus erythematosus. Neurology 1992; 42(9):1649-57.

7. Liem MD, Gzesh DJ, Flanders AE. MRI and angiographic diagnosis of lupus cerebral vasculitis. Neuroradiology 1996; 38(2):134-6.

8. Sibbitt WL, Brandt JR, Johnson CR, et al. The incidence and prevalance of neuropsychiatric syndromes in pediatric onset systemic lupus erythematosus. J Rheumatol 2002;29(7):1536- 42.

9. Govoni M, Castellino G, Padovan M, et al. Recent advances and future perspective in neuroimaging neuropsychiatric systemic lupus erythematosus. Lupus 2004;13(3):149-58.
10. Fanouriakis A, Pamfil C, Sidiropoulos $P$, et al. Cyclophosphamide in combination with glucocorticoids for severe neuropsychiatric systemic lupus erythematosus: A retrospective, observational two-centre study. Lupus 2016;25(6): 627-36.

11. Barile-Fabris L, Ariza-Andraca $R$, Olguin-Ortega L, et al. Controlled clinical trial of IV cyclophosphamide versus IV methylprednisolone in severe neurological manifestations in systemic lupus erythematosus. Ann Rheum Dis 2005;64(4):620-5. 